Trakya Eğitim Dergisi

Cilt 9, Sayı 1

Ocak 2019, 44-60

Geliş Tarihi: 03.08.2018

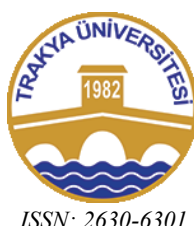

ISSN : 2630-6301
Trakya Journal of Education

Volume 9, Issue 1

January 2019, 44-60

\title{
İlkokul 4. Sınıf Öğrencilerinin Dijital Oyun Bağımlılıklarının Çeşitli Değişkenler Açısından İncelenmesi ${ }^{1}$
}

\author{
Investigation of 4th Grade Elementary School Student's Digital Game Addiction
}

\author{
Ayşe Hilal ORAL ${ }^{2}$, Taner ARABACIOĞLU ${ }^{3}$,
}

\begin{abstract}
Öz: Bu araştırmanın amacı ilkokul 4. sınıf öğrencilerinin dijital oyun bağımlılıklarının çeşitli değişkenler açısından incelenmesidir. Araştırmanın örneklemini 2016-2017 eğitim öğretim yılında Denizli ili merkez ilçelerinde bulunan 6 ilkokulda 4. sınıfta öğrenim gören 302 öğrenci oluşturmaktadır. Araştırmada veri toplama amacıyla araştırmacı tarafından geliştirilen Bilişim Teknolojileri Kullanım anketi ve Dijital Oyun Bağımlılığı ölçeği uygulanmıștır. Elde edilen verilerin analizinde betimsel istatistik yöntemleri ve Chaid Analizi kullanılmıştır. Araştırma sonucunda, araştırmaya katılan öğrencilerin \%13,9'unun dijital oyun bağımlısı olduğu ve öğrencilerin dijital oyun bağımlılığını etkileyen en önemli yordayıcı değişkenin cinsiyet olduğu görülmüştür. Cinsiyet değişkeninde, erkek öğrencilerin dijital oyun bağımlılıklarını en iyi açıklayan bağımsız değişken oyun oynama sıklığı iken kız öğrencilerin dijital oyun bağımlılıklarını en iyi açıklayan bağımsız değişken, başkasının facebook hesabını kullanma değişkenidir.
\end{abstract}

Anahtar sözcükler: Dijital Oyun Bağımlılı̆̆l, İlkokul ögrencileri, bilişim teknolojileri

\begin{abstract}
The aim of this research is to investigate the digital game addictions of primary school 4th grade students through some variables. The sample group of the research consisted of 302 students of 4th grade who studied in 6 primary schools located in the districts of Denizli in the academic year of 2016-2017. For the purpose of collecting data in the research, "Usage of Information Technologies" survey and "Digital Game Addiction" scale were applied. Descriptive statistical methods and Chaid Analysis were used in the analysis of the obtained data. As a result of the research, it was found that $13.9 \%$ of the students who participated in the research were digital game addicts and that the most important predictive variable affecting the digital game addiction of the students was gender. In the gender argument, the variable that best describes the digital game dependencies of female students is the usage of Facebook account by other people, while the best variable describing the addiction of male students is the game playing frequency.
\end{abstract}

Keywords: Digital Game Addiction, Primary School Students, Information technologies

Cite this article as:

Oral, A. H., \& Arabacığlu, T. (2019). İlkokul 4. Sınıf öğrencilerinin dijital oyun bağımlılıklarının çeşitli değişkenler açısından incelenmesi. Trakya Ĕ̆itim Dergisi, 9(1), 44-60.

\section{Introduction}

\section{EXTENDED ABSTRACT}

The widespread use of computers, tablets and smartphones affects the game habits of primary school students. The games played with friends have been replaced by digital games. Yalçın Irmak and Erdoğan (2016) suggest this fact is due to digital games being a symbol of popular culture and show that young people are more interested in digital games. When the effects of digital games on individuals are examined, While Hamlen (2018) argues that digital games may have a positive impact on solving real-life problems styles; Eichenbaum, Bavelier and Green (2014) claims that they may have an impact on the development of basic perceptual and cognitive skills, and Curtis and Lawson (2002) on problemsolving performances. On the other hand, Granic, Lobel and Engels (2014) highlight the negative effects of digital games such as violence, addiction and depression. When the researches are analyzed, it is seen that there are many studies related to digital game addiction (Gökçearslan and Durakoğlu, 2014; Arıcak, Dinç, Yay and Griffiths, 2019; Aydoğdu Karaaslan, 2015). However, few studies (Toran, Ulusoy, Aydın, Deveci and Akbulut, 2016; Hazar and Caspian, 2017) have been found in primary school level. This study tries to identify digital game addiction depending on the demographic variables

\footnotetext{
${ }^{1} \mathrm{Bu}$ çalışma, birinci yazarın ikinci yazar danışmanlığında hazırladığı yüksek lisans tezinden üretilmiştir ve çalışmanın bir bölümü 02-04 Mayıs 2018 tarihleri arasında İzmir'de düzenlenen 12. Uluslararası Uluslararası Bilgisayar ve Öğretim Teknolojileri Sempozyumu'nda sözlü bildiri olarak sunulmuştur.

${ }^{2}$ BilimUzman1, e-posta: ayse.4124@gmail.com

${ }^{3}$ Dr. Öğr. Üyesi, Aydın Adnan Menderes Üniversitesi, e-posta: tarabacioglu@adu.edu.tr
} 
of the fourth graders and the frequency of their using digital tools. In this context, the general aim of the study is to investigate the digital game addiction among the 4th grade students.

In order to achieve this aim, answers to the following questions were sought;

1. What is the distribution of the use of information and communication technologies and the digital playing habits of the 4 th grade students?

2. Can gender, having a smart phone, frequency of smartphone use, frequency of digital play, having a Facebook account, logging into someone else's Facebook account, and socio-economic level variables significantly differentiate 4 th graders in terms of digital game addiction?

\section{Method}

In the research, screening method -one of the quantitative research designs- was used. In the screening method, it is aimed to describe the characteristics of a population and to determine the causes or consequences of the differences between the groups by causal comparison method (Fraenkel \& Wallen, 2009). The sample of the study consisted of 302 fourth graders studying in the central districts of Denizli in 2016-2017 academic year. Disproportionate stratified sampling was used to determine the participants. The pilot application was carried out with 95 fourth graders in three primary schools in Efeler district of Aydın province.

In order to collect data, validity and reliability analyses were conducted for the purpose of extension the Digital Game Addiction Scale developed by Valkenburg and Peter (2009) and adapted into Turkish by Yalçın Irmak and Erdoğan (2015). Validity (exploratory factor analysis) and reliability (cronbach's alpha, inter-item correlation matrix, item-total statistics) analyses were performed using the pilot data. Confirmatory factor analysis was performed to verify the structure revealed by the pilot application data.

\section{Results and Discussion}

As Lemmens, Valkenburg and Peter (2009) stated that students who mark 3 or more at least half of the total number of items have been identified as digital game addicts. Then Chaid analysis was performed to determine the variables that significantly differentiate digital game addiction. According to the results of the study, 4th grade students often use the internet to conduct research and play digital games. It is seen that the students use media tools in accordance with certain rules. The most frequently used social media tool is Facebook. More than half of the students (53\%) stated that they had their own Facebook accounts.

When the digital game addiction of the students is analyzed, it can be claimed that $14 \%$ is a digital game addict. It is seen that the most important predictor variable affecting digital game addiction is gender. Male students are more dependent than female students. Griffiths and Hunt (1995), Griffiths and Davies (2005), Erboy (2010), Horzum (2011), Sahin and Tugrul (2012), Vollmer, Randler, Horzum and Ayas (2014), Bilgin (2015) have reached similar conclusions in their research. The second variable predicting addiction in male students was the frequency of digital game playing. Male students who play digital games more than three days a week, tend to become addicts.

\section{GİRIŞ}

Bilişim teknolojilerinde yaşanan hızlı değişim sonucu masaüstü bilgisayarlar taşınabilir bilgisayarlara dönüşmekte, radyolar ile başlayan medya araçlarının kullanımı ise sosyal medyaya evrilmektedir. Uydu yayınları, akıllı telefonlar ile her an her yerde internete ulaşabilme olanağı, internet üzerinden binlerce kişinin aynı anda oynayabildiği oyunlar ve sosyal medya aracıllı̆ıyla iletişimin kitlesel bir büyüklüğe ulaşması söz konusu değişimin somut örneğidir.

Bilişim teknolojilerinde yaşanan değişim bireylerin tümünde aynı etkiyi göstermemekte, farklı algılara ve bazı bireylerde bağımlılık gibi istenmeyen sonuçlara neden olabilmektedir. Bu durumun temelinde bireylerin doğdukları dönemdeki teknoloji varlığı önemli rol oynamaktadır. Sprenger (2010) kuşakları TV, X, Y ve Z olarak adlandırmaktadır. Bu durum birçok farklı çalışmaya konu olmuştur (Alwin, 2002; Çukurbaşı ve İşman, 2014, Yüksekbilgili, 2015). Z kuşağını oluşturan günümüz ilk ve orta öğretim öğrencilerini, diğer öğrencilerden ayıran özelliklerden en önemlisi, değişimi keskin ve hızlı bir şekilde yaşamaları ve kuşak özelliklerinin onlar doğmadan önce tanımlanmış olmasıdır (Altıntuğ, 2012). Teknolojinin kullanıldığı bir ailede büyüyen $Z$ kuşağı, diğer kuşakların ilk kez kullandıkları araç ve teknolojiler ile oyun oynayarak büyümektedir. RTÜK tarafından yapılan Türkiye'de Çocukların 
Medya Kullanma Alışkanlıkları Araştırması (2013) verilerine göre öğrencilerin \%97,9'u televizyon, $\% 73,7$ 'si bilgisayar/tablet bilgisayar, \%63'ü internet, 44,6's1 sabit telefon ve 38,3'ü radyo sahibidir. 2017 yılı Nisan ayında gerçekleştirilen TÜİK Hanehalkı Bilişim Teknolojileri Kullanım Araştırması verilerine göre ise bireylerin \%67'si internet kullanırken, internet erişimi olan hanelerin oranı \%81 olmuştur. Türkiye'de hanelerin bilişim teknolojileri sahiplik oranlarına bakıldığında cep-akıllı telefon bulunan hanelerin oranı $\% 98$, masaüstü bilgisayar sahipliği oranı $\% 20$, taşınabilir bilgisayar $\% 37$, tablet bilgisayar \%30 ve internet bağlantısı olan televizyon sahipliği oranı \%29'dur. Söz konusu araştırmanın hanelerde bilişim teknolojileri bulunma oranlarına ait 2004-2017 yılları arasındaki veriler incelendiğinde, masaüstü bilgisayar oranlarının 2011 yılından itibaren düşüşe geçmesi, akıllı telefon, tablet bilgisayar, taşınabilir bilgisayar ve internet bağlantısı olan televizyon sahipliği oranlarının ise sürekli artış göstermesi dikkati çekmektedir.

Benzer bir araştırma Deveci vd. (2007) tarafindan ilköğretim öğrencilerinin elektromanyetik araçları (telefon, bilgisayar, TV gibi) hangi sıklıkla kullandıklarını incelemek amacıyla yapılan çalışmada; öğrencilerin \%25,9'u cep telefonu kullandı̆̆,$\% 11$ 'nin kendine ait cep telefonu olduğu, $\% 59,3$ 'ü bilgisayar kullandığı ve bilgisayar kullananların \%56,5'i bilgisayarı sadece oyun amaçlı kullandığı, \%99,9’u televizyon izlediği görülmüştür.

Dijital medya araçları son zamanlarda internet ile eşdeğer görülmektedir. Bunun nedeni olarak medya araçlarının çoğundan internet erişiminin sağlanabilmesi söylenebilir. Sakarya, Tercan ve Çoklar (2011) internetin kullanım amaçlarını incelediği çalışmada ulaştığı sonuçlara göre internette bilgi arama ilk sıradadır. Bilgi aramayı oyun, haberleşme, eğlence, film veya müzik, haberleri takip etme ve diğer amaçlar takip etmektedir. Sosyal medya aracı olarak ise çocuklar en fazla Facebook ve Youtube kullanmaktadır (Atal ve Usluel, 2011). Ebeveynlerin büyük çoğunluğu çocukların hesap şifresini bilmektedir ancak çocukların internette güvende olmadığını düşünmektedir (Ulusoy ve Bostancı, 2014).

$\mathrm{Bu}$ araçların yaygınlaşması oyun çağında olan ilkokul öğrencilerinin alışkanlıklarını da etkilemiş, arkadaşlarla oynanan oyunların yerini dijital ortamdaki oyunlar almaya başlamıştır. Bu durumu Yalçın Irmak ve Erdoğan (2016) dijital oyunların popüler kültür simgesi olarak açılamakta ve gençlerin dijital oyunlara daha fazla ilgi gösterdiklerini ifade etmektedir. Bunun nedeni olarak bilgi ve iletişim teknolojilerinde yaşanan gelişimler olduğu söylenebilir. Söz konusu gelişim sonucunda bilgisayar oyunları sadece günlük yaşamın bir parçası değil üniversitelerde programları olan ve akademik bir disiplin olarak kabul edilmektedir (Bostan ve Tıngöy, 2015). Dijital oyunların tarihsel gelişimi incelendiğinde O'Hagan (2018) 1970'lerin başında Atari ve 1980'lerin ortasında Nintendo firmalarının önemli bir yer tuttuğunu belirtmektedir. Oyun endüstrisi perspektifinden bakıldığında ise tarihsel gelişimi 4 aşamada sunmaktadır. Bunlar; erken evre (1980'lerin ortasına kadar olan dönem), büyüme evresi (1990'ların ortasına kadar), gelişme evresi (1990'ların sonuna kadar), olgunlaşma evresi (20002005 arası) ve ileri evre (2005 sonrası) olarak ifade eilmektedir. Dijital oyunların bireyler üzerindeki etkileri incelendiğinde; Hamlen (2018) dijital oyunların bireylerin gerçek yaşam problemlerini çözme stilleri üzerinde, Eichenbaum, Bavelier ve Green (2014) temel algısal ve bilişsel becerilerin gelişiminde, Curtis ve Lawson (2002) ise problem çözme performansları üzerinde etkili olabileceğini ifade etmektedir. Ancak Granic, Lobel ve Engels (2014) belirtilen olumlu etkilerin yanında şiddet, bağımlılık ve depresyon gibi olumsuzluklara dikkat çekmektedir. Yapılan araştırmalar incelendiğinde gerek yurt dışında gerekse Türkiye'de dijital oyun bağımlılı̆̆ıyla ilgili pek çok çalışma yapıldığ 1 görülmektedir (Gökçearslan ve Durakoğlu, 2014; Arıcak, Dinç, Yay ve Griffiths, 2019; Aydoğdu Karaaslan, 2015). Ancak ilkokul düzeyinde dijital oyun bağımlılığına ilişkin az sayıda çalışmaya (Toran, Ulusoy, Aydın, Deveci ve Akbulut, 2016; Hazar ve Hazar, 2017) rastlanmıştır. Bu araştırmada ilkokul dördüncü sınıf öğrencilerinin demografik özellikleri ve dijital araçları kullanma alışkanlıkları sonucunda bağımlılık durumlarını belirlenmeye çalışılmıştır. Çalışmanın alandaki söz konusu eksikliği gidermeye katkı sağlayacağı ve bundan sonra yapılacak araştırmalar için araştırmacılara farklı bir bakış açısı kazandırarak veri niteliğinde yol göstereceği düşünülmektedir. Ayrıca ilkokul 4. Sınıf öğrencilerinin bilgi ve iletişim teknolojileri kullanım alışkanlıkları ile ilgili yapılacak bu araştırmada; söz konusu araçlar ve bu araçların kullanımını etkileyen değişkenlerin tespit edilmesi yönüyle alınabilecek önlemler açısından öğretmenlere ve velilere fikir vereceği düşünülmektedir. Bu bağlamda çalışmanın genel amacı ilkokul 4. sınıf öğrencilerinin dijital oyun bağımlılıklarının çeşitli değiş̧enler açısından incelenmesidir.

$\mathrm{Bu}$ amacı gerçekleştirebilmek için aşağıdaki sorulara yanıt aranmıştır;

1. İlkokul 4. Sınıf öğrencilerinin bilgi ve iletişim teknolojileri kullanımı ile dijital oyun oynama alışkanlıklarının dağglımı ne yöndedir? 
2. Cinsiyet, akıllı telefona sahip olma, akıllı telefon kullanım sıklığı, dijital oyun oynama sıklı̆ğ, facebook hesabının olması, başkasının Facebook hesabına giriş yapma ve sosyo-ekonomik düzey değişkenleri, ilkokul 4. Sınıf öğrencilerini dijital oyun bağımlılı̆̆ bakımından manidar bir şekilde ayırabilmekte midir?

\section{YÖNTEM}

\subsection{Araştırma Deseni}

Araştırma ile ilkokul 4. sınıf öğrencilerinin bilgisayar, tablet bilgisayar ve akıllı telefon kullanım alışkanlıklarının belirlenmesi amaçlandığından nicel araştırma desenlerinden tarama yöntemi işe koşulmuştur. Tarama yöntemi ile bir popülasyonun özelliklerini betimlemek, nedensel karşılaştırma yöntemi ile de gruplar arasındaki farklılıkların nedenleri ya da sonuçlarını belirlemek amaçlanmaktadır (Fraenkel \& Wallen, 2009).

\subsection{Evren ve Örneklem}

Araştırmanın evrenini 2016-2017 eğitim öğretim yılında Denizli ili merkez ilçelerinde öğrenim gören 4234 dördüncü sınıf öğrencisi oluşturmaktadır. Örnekleme ilkokul dördüncü sınıf öğrencilerinin seçilmesinin nedeni, uygulanacak Likert tipi ölçme aracına Piaget'in Bilişsel Gelişim Kuramı bağlamında daha güvenilir yanıtlar alınacağı düşüncesidir. Söz konusu evren içerisinden orantısız tabakalı örnekleme yoluyla örneklem alınmıştır. Orantısız tabakalı örnekleme, tabaka ağırlıklarının dikkate alınmadığı, her bir tabaka için eşit ağırlıkta seçkisiz olarak birimlerin belirlendiği örnekleme yöntemidir (Erkuş, 2017). Denizli'deki okulların adlarının yer aldığı liste alt, orta ve üst sosyo ekonomik düzey (SED) gruplarına ayrılarak her gruptan tesadüfi iki okul belirlenmiş ve toplam 6 ilkokuldaki 4. Sınıf öğrencileri araştırmanın örneklemini oluşturmuştur.

Okulların düzeyi, bulundukları bölge dikkate alınarak ve İl Milli Eğitim Müdürlügü̈nnün görüşü doğrultusunda belirlenmiştir. Bu okullar; Yüksek sosyo-ekonomik düzey için Yüksek 1 ve Yüksek 2, orta sosyo-ekonomik düzey için Orta 1 ve Orta 2, düşük sosyo-ekonomik düzey için ise Düşük 1 ve Düşük 2 şeklinde kodlanmıştır. Araştırmanın örneklemini 146 kız, 156 erkek olmak üzere toplam 302 ilkokul 4. sınıf öğrencisi oluşturmaktadır. Örneklemi oluşturan öğrencilerin okullara göre dağılımını belirten veriler Tablo 1 'de verilmiştir.

Tablo 1. Örneklemi oluşturan öğrencilerin okullara göre dağılımı

\begin{tabular}{lcc}
\hline & Öğrenci Sayısı & Toplam \\
Düşük 1 & 50 & 97 \\
Düşük 2 & 47 & 98 \\
Orta 1 & 50 & \\
Orta 2 & 48 & 107 \\
Yüksek 1 & 55 & 57 \\
Yüksek 2 & 52 & \\
\hline
\end{tabular}

Öğrencilerin 97'si düşük sosyo-ekonomik düzeyden seçilen okullarda, 98'i orta sosyo-ekonomik düzeyden seçilen okullarda, 107'si ise yüksek sosyo-ekonomik düzeyden seçilen okullarda öğrenim görmektedir. Düşük SED'den seçilen 1. okuldan (Düşük 1) araştırmaya katılan 50 öğrencinin 25'i kız, 25'i erkek 2. okuldaki (Düşük 2) 47 öğrencinin ise 26'sı kız, 21'i erkektir. Orta 1'deki 50 öğrenciden 23'ü kız, 27'si erkek; Orta 2'deki 48 öğrenciden 24'ü kız, 24'ü erkek; Yüksek 1'deki 55 öğrenciden 25'i kız, 30’u erkek; Yüksek 2'deki 52 öğrenciden 23'ü kız, 29’u erkek öğrencilerdir.

\subsection{Veri Toplama Araçları}

Ortaya konan araştırma deseni çerçevesinde veri toplama aracı olarak araştırmacılar tarafından hazırlanan Bilişim Teknolojileri Kullanım anketi ve Dijital Oyun Bağımlılığı Ölçeği kullanılmıştır. Bilişim teknolojileri kullanım anketinde demografik sorular ve kullanılan bilişim teknolojileri araçları ile kullanım sıklıkları ve öğrencilerin sosyal medya kullanımlarını belirlemeye yönelik 20 adet soru bulunmaktadır. Ayrıca, Valkenburg ve Peter (2009) tarafından geliştirilen ve Yalçın Irmak ve Erdoğan (2015) tarafından Türkçeye uyarlanan Dijital Oyun Bağımlılığı Ölçeğine ranj genişletme amacıyla geçerlik ve güvenirlik analizleri yapılmıştır. Belirtilen ölçme aracının lisans ve ortaöğretim örnekleminde geliştirilmiş olması nedeniyle, araştırmada kullanılabilmesi için uzman görüşü ardından pilot çalışma ile araştırma örneklemine uygunluğu test edilmiştir. Bu bağlamda ölçek öncelikle 
Psikolojik Danışmanlık ve Rehberlik Anabilim Dalı uzmanı 3 öğretim üyesinin görüşüne sunulmuştur. Alınan dönütler doğrultusunda düzenlemeler yapılmıştır. İkinci aşamada ise 2015-2016 eğitim-öğretim yılında ilkokul 4 sınıf öğretmenliği yapan 2 sınıf öğretmeni ile paylaşılmış ve düşünceleri doğrultusunda düzenlemeler yapılmıştır. Bir ölçme değerlendirme uzmanın verdiği dönütler doğrultusunda da ölçeğe son hali verilmiştir.

\subsection{Pilot Uygulama}

Uzman görüşleri doğrultusunda yapılandırılan ölçeğin anlaşılabilirliği ile geçerlik ve güvenirlik analizlerini yapabilmek için 2016-2017 eğitim öğretim yılı güz döneminde Aydın ili Efeler ilçesindeki üç ilkokulda pilot uygulama gerçekleştirilmiştir. Örneklem oluşturulurken tabakalı örnekleme yöntemiyle öğrencilerin sosyo-ekonomik durumları göz önüne alınarak seçilen üç ilkokulda uygulama yapılmıştır. Bu okullar; düşük SED için Düşük, orta SED için Orta ve yüksek SED için Yüksek olarak kodlanmıştır. Eksik ya da hatalı doldurulan ölçekler analize dahil edilmemiş, uygun kabul edilen 95 öğrencinin yanıtlamış olduğu ölçeklerin analizleri değerlendirilmiştir. Örneklem sayısı madde sayısının en az on katı olacak şekilde belirlenmiştir. Büyüköztürk'e (2002) göre genel bir kural olarak örneklem büyüklüğünün en az gözlenen değişken sayısının beş katı olması gerekmektedir. Tavşancıl (2002) da örneklem büyüklügünün madde sayısının en az beş katı, hatta on katı civarında olması gerektiğini belirtmiștir.

Dijital Oyun Bağımlılığ Ölçeğindeki maddeler için açımlayıcı faktör analizi uygulanmıştır. Açımlayıcı faktör analizi 4'lü likert tipinde (Hiçbir zaman, Nadiren, Bazen, Sık sık) sıklık ölçen, 7 madde ile gerçekleştirilmiştir. Ölçek maddelerine açımlayıcı faktör analizi yapılıp yapılamayacağını kontrol etmek amaciyla KMO değerinden ve Bartlett testinden yararlanılmıştır. Maddelerin faktörlenebilirliğinin bir ölçütü olarak kabul edilen KMO değeri 0,82 ve Bartlett testinden elde edilen $\chi 2$ istatistiği $\alpha=0,001$ düzeyinde anlamlı bulunmuştur $\left(\chi^{2}=132,80, p=.000\right)$. Bu durum faktör analizi için örneklemin uygunluğuna işaret etmektedir.

Açımlayıcı faktör analizi döndürme tekniği uygulanmadan yapılmış, maddelerin tek bir faktör altında toplandığı ve \%41.88 varyans açıklama oranına ulaştığı görülmüş̧ür. Ölçekte yer alan 7 maddenin faktörlerdeki yük değerleri .787 ile .472 arasında değişmektedir. Maddelerin yük değerleri, varyans açıklama oranları Tablo 2'de, güvenirliğe ait değerler ise Tablo 3 ve Tablo 4'de verilmiştir.

Tablo 2. Maddelerin yük değerleri, faktör varyans açıklama oranı

Madde

1. Bir bilgisayar oyununu tüm gün boyunca oynamak isterim

2. Oyun için harcadığım zamanı giderek artırırım.

3. Günlük yaşamdan uzaklaşmak için oyun oynarım.

4. Annem, babam ya da arkadaşlarım sayesinde daha az bilgisayar oyunu oynarım.

5. Oyun oynamadığım zaman kendimi kötü hissederim.

6. Bilgisayar oyununda harcadığım zaman konusunda annem ya da babamla sorun yaşarım.

7. Bilgisayar oyunu oynamak için ödevlerimi ihmal ederim. Açıklanan varyans
Yük Değeri

.734

.787

.667

.472

.529

.655

.630

41.883

“Dijital Oyun Bağımlılığı” ölçeğinin güvenirlik analizi için cronbach alpha iç tutarlılık katsayıSı .756 olarak hesaplanmıştır. Pallant'a (2015) göre bu değer kabul edilebilir olarak değerlendirilmektedir. Değişkenler arasındaki korelasyon matrisi (inter-item correlation matrix) Tablo 3'de verilmiştir.

Tablo 3. Değişkenler arasındaki korelasyon matrisi

\begin{tabular}{lccccccc}
\hline & Madde 1 & Madde 2 & Madde 3 & Madde 4 & Madde 5 & Madde 6 & Madde 7 \\
\hline Madde 1 & 1,000 &, 481 &, 382 &, 320 &, 234 &, 438 &, 354 \\
Madde 2 &, 481 & 1,000 &, 496 &, 311 &, 290 &, 405 &, 429 \\
Madde 3 &, 382 &, 496 & 1,000 &, 137 &, 274 &, 320 &, 315 \\
Madde 4 &, 320 &, 311 &, 137 & 1,000 &, 104 &, 212 &, 234 \\
Madde 5 &, 234 &, 290 &, 274 &, 104 & 1,000 &, 320 &, 288 \\
Madde 6 &, 438 &, 405 &, 320 &, 212 &, 320 & 1,000 &, 225 \\
Madde 7 &, 354 &, 429 &, 315 &, 234 &, 288 &, 225 & 1,000 \\
\hline
\end{tabular}


Tablo 3 incelendiğinde tüm değerlerin pozitif olduğu görülmektedir. Pallant'a (2015) göre pozitif değerler, maddelerin aynı özelliği ölçtüğünün bir göstergesidir. Madde 4 ile madde 3 , madde 5 , madde 6 ve madde 7 arasındaki korelasyonun düşük olması, 4 numaralı maddenin söz konusu diğer maddeler ile aynı özelliği ölçtüğü noktasında soru işaretleri barındırmaktadır. Güvenirliği belirlemede diğer bir kriter olarak madde-toplam istatistikleri tablosu kontrol edilmelidir. Söz konusu istatistikler Tablo 4'de verilmiştir.

Tablo 4. Madde-toplam istatistikleri

\begin{tabular}{lrrrr}
\hline & $\begin{array}{c}\text { Madde silindiğinde } \\
\text { ölçek ortalamas1 }\end{array}$ & $\begin{array}{c}\text { Madde silindiğinde } \\
\text { ölçek varyans1 }\end{array}$ & $\begin{array}{c}\text { Düzeltilmiş madde- } \\
\text { toplam korelasyonu }\end{array}$ & $\begin{array}{c}\text { Madde silindiğinde } \\
\text { Cronbach Alpha değeri }\end{array}$ \\
\hline Madde 1 & 10,43 & 14,014 &, 575 &, 704 \\
Madde 2 & 10,59 & 13,968 &, 635 &, 692 \\
Madde 3 & 10,59 & 15,032 &, 486 &, 724 \\
Madde 4 & 10,17 & 15,333 &, 325 &, 764 \\
Madde 5 & 10,53 & 15,592 &, 370 &, 749 \\
Madde 6 & 10,72 & 14,950 &, 492 &, 723 \\
Madde 7 & 10,81 & 15,304 &, 469 &, 728 \\
\hline
\end{tabular}

Tablo 4 incelendiğinde düzeltilmiş madde-toplam korelasyon değeri her bir maddenin toplam puanla olan ilişkisini belirler. Bu bağlamda .3 altında bir puanın olmaması tüm maddelerin aynı özelliği ölçtüğünün bir göstergesidir. Bunun yanında madde silindiğinde elde edilecek Cronbach alpha değeri, hesaplanan Cronbach alpha değerinden büyük olmaması da Pallant'a (2015) göre yeni ölçek geliştirirken dikkat edilmesi gereken noktalardan birisidir. Tablo 4'de verilen Madde-Toplam istatistiklerine göre 4 numaralı maddenin silinmesi halinde Cronbach alpha değerinin arttığ görülmektedir (İç tutarlılık katsayısı $\alpha=.756$ değerinden, $\alpha=.764$ değerine artış göstermektedir.) $\mathrm{Bu}$ durumda değişkenler arasındaki korelasyon matrisindeki veriler ile birlikte değerlendirildiğinde Dijital Oyun Bağımlılığı ölçeğinin nüksetme boyutuna karşılık gelen 4 numaralı maddenin analiz dışı bırakılarak, güvenirlik analizlerinin tekrarlanmasının uygun olacağına karar verilmiştir. Bu bağlamda tekrarlanan açımlayıcı faktör analizi sonuçları Tablo 5' de, güvenirlik analizleri sonuçları ise Tablo 6 ve Tablo 7' de verilmiştir.

Tablo 5. Maddelerin yük değerleri, faktör varyans açıklama oranı

Madde

1. Bir bilgisayar oyununu tüm gün boyunca oynamak isterim

2. Oyun için harcadığım zamanı giderek artırırım.

3. Günlük yaşamdan uzaklaşmak için oyun oynarım.

5. Oyun oynamadığım zaman kendimi kötü hissederim.

6. Bilgisayar oyununda harcadığım zaman konusunda annem ya da babamla sorun yaşarım.

7. Bilgisayar oyunu oynamak için ödevlerimi ihmal ederim. Açıklanan varyans
Yük Değeri

$$
\begin{gathered}
.726 \\
.786 \\
.694 \\
.554 \\
.664 \\
.632 \\
46.228
\end{gathered}
$$

Tablo 5'de görüldüğü üzere Madde 4'ün açımlayıcı faktör analizinden çıkartılması sonrasında maddelerin yine tek bir faktör altında toplandığı ve varyans açıklama oranının \%46.23'e ulaştığ görülmüştür. Ölçekte yer alan 6 maddenin faktörlerdeki yük değerleri .786 ile .554 arasında değişmektedir. Ayrıca Cronbach alpha katsıyısı .764 olarak bulunmuştur. Güvenirliğe ait değerler ise Tablo 6 ve Tablo 7'de verilmiştir.

Tablo 6. Değişkenler arasındaki korelasyon matrisi

\begin{tabular}{lcccccc}
\hline & madde1 & madde2 & madde3 & madde5 & madde6 & madde7 \\
Madde1 & 1,000 &, 481 &, 382 &, 234 &, 438 &, 354 \\
Madde2 &, 481 & 1,000 &, 496 &, 290 &, 405 &, 429 \\
Madde3 &, 382 &, 496 & 1,000 &, 274 &, 320 &, 315 \\
Madde5 &, 234 &, 290 &, 274 & 1,000 &, 320 &, 288 \\
Madde6 &, 438 &, 405 &, 320 &, 320 & 1,000 &, 225 \\
Madde7 &, 354 &, 429 &, 315 &, 288 &, 225 & 1,000 \\
\hline
\end{tabular}


Tablo 6 incelendiğinde tüm değerlerin pozitif olduğu görülmektedir. Madde 1 ile madde 5 ve madde 6 ile madde 7 arasındaki korelasyonun .20'ye yakın değerler verdiği ayrıca madde 5 ile madde2, madde3, madde 7 arasındaki korelasyon değerlerinin .30 altında olmakla birlikte .30 'a oldukça yakın değerler içerdiği görülmektedir. Söz konusu verilerin değerlendirilmesinde, güvenirliği belirlemede diğer bir kriter olarak madde-toplam istatistikleri tablosu kontrol edilmelidir. Söz konusu istatistikler Tablo 7'de verilmiştir.

Tablo 7. Madde-toplam istatistikleri

\begin{tabular}{lcccc} 
& $\begin{array}{c}\text { Madde silindiğinde } \\
\text { ölçek ortalaması }\end{array}$ & $\begin{array}{c}\text { Madde silindiğinde } \\
\text { ölçek varyansı }\end{array}$ & $\begin{array}{c}\text { Düzeltilmiş madde- } \\
\text { toplam korelasyonu }\end{array}$ & $\begin{array}{c}\text { Madde silindiğinde } \\
\text { Cronbach Alpha değeri }\end{array}$ \\
madde1 & 8,29 & 10,614 &, 550 &, 717 \\
madde2 & 8,45 & 10,506 &, 624 &, 697 \\
madde3 & 8,45 & 11,187 &, 518 &, 726 \\
madde5 & 8,39 & 11,687 &, 393 &, 759 \\
madde6 & 8,58 & 11,268 &, 495 &, 732 \\
madde7 & 8,67 & 11,648 &, 460 &, 740 \\
\hline
\end{tabular}

Tablo 7 incelendiğinde her bir maddenin toplam puanla olan ilişkisini belirleyen düzeltilmiş madde-toplam korelasyon değerlerinin .30 altında bir puanın olmaması tüm maddelerin aynı özelliği ölçtügünün bir göstergesidir Ayrıca madde silindiğinde elde edilecek Cronbach alpha değerleri .764 olarak hesaplanan iç tutarlılık katsayısının üstünde bir değere çıkmamıştır.

Sonuç olarak, 4 numaralı maddenin analiz dışı bırakılması sonucunda varyans açıklama oranı ile madde yük değerlerindeki artışın yanında, güvenirlik analizlerindeki korelasyon değerleri ile birlikte madde silindiğinde elde edilecek Cronbach Alpha değerinin düşmemesi göz önüne alındığında söz konusu maddenin ölçme aracı dışında bırakılmasına karar verilmiştir. $\mathrm{Bu}$ sonuçlar Dijital Oyun Bağımlılı̆̆ anlaşılmadığını düşündürmektedir. Açımlayıcı Faktör Analizi sonucunda, 4 numaralı madde çıkarıldığında ölçek maddelerinin faktöre .40'1n üzerinde yük vermesi, \% 46'lık açılama oranı ve .70 üzerindeki iç tutarlılık katsayısı ile söz konusu ölçeğin asıl uygulama için kullanılabilir olduğunun birer göstergesi olarak değerlendirilebilir.

\subsection{Dijital Oyun Bağımlılığı Ölçeği Doğrulayıcı Faktör Analizi}

Doğrulayıcı faktör analizi ile açımlayıcı faktör analizi sonucu elde edilen altı maddeden oluşan dörtlü likert tipindeki yapının doğrulanıp doğrulanmadığı, asıl uygulama örneklemi ile test edilmiştir. Söz konusu grup, 146 kız ve 156 erkek öğrenci olmak üzere 302 öğrenciden oluşmaktadır. Birinci düzey doğrulayıcı faktör analizinde en çok olabilirlik tahmin yöntemi kullanılarak test edilmiştir. Analiz sonucunda elde edilen uyum indeksleri ve Şimşek (2007) tarafindan ortaya konan uyum ölçütleri Tablo 8 'de sunulmuştur.

Tablo 8. Modelin DFA Uyum Ölçütleri

\begin{tabular}{lllc}
\hline \multicolumn{1}{c}{ Uyum Ölçüleri } & İyi Uyum & Kabul Edilebilir Uyum & Model puanı \\
\hline$\chi^{2} / \mathrm{df}$ & $\leq 3$ & $\leq 5$ & $19.46 / 9=2.17$ \\
RMSEA & $\mathrm{RMSEA}<.05$ & $.05<\mathrm{RMSEA} \leq .08$ & 0.062 \\
$\mathrm{RMR}$ & $\mathrm{RMR}<.05$ & $\mathrm{RMR}<.08$ & 0.025 \\
$\mathrm{SRMR}$ & $\mathrm{SRMR} \leq .05$ & $\mathrm{SRMR} \leq .80$ & 0.039 \\
$\mathrm{NFI}$ & $.95 \leq \mathrm{NFI} \leq 1$ & $.90 \leq \mathrm{NFI}<.95$ & 0.96 \\
$\mathrm{IFI}$ & $.95 \leq \mathrm{IFI} \leq 1$ & $.90 \leq \mathrm{IFI}<.95$ & 0.98 \\
RFI & $.95 \leq \mathrm{RFI} \leq 1$ & $.90 \leq \mathrm{RFI}<.95$ & 0.93 \\
CFI & $.95 \leq \mathrm{CFI} \leq 1$ & $.90 \leq \mathrm{CFI}<.95$ & 0.98 \\
GFI & $.95 \leq \mathrm{GFI} \leq 1$ & $.90 \leq \mathrm{GFI}<.95$ & 0.98 \\
AGFI & $.95 \leq \mathrm{AGFI} \leq 1$ & $.90 \leq \mathrm{AGFI}<.95$ & 0.95 \\
\hline
\end{tabular}

Uyum indeksleri incelendiğinde RMSEA ve RFI değerlerinin kabul edilebilir, diğer tüm değerlerin iyi uyum indekslerine sahip olduğu görülmektedir. Bu bulgulara dayanarak ölçeğin yap1 geçerliğinin sağlandığı söylenebilir. Söz konusu indeksler yanında, AFA ile ortaya konan yapının DFA ile doğrulandığının belirlenmesinde, $t$ değerlerinin de manidarlık düzeyleri incelenmelidir. Uyum 
indeksleri ve $t$ değerlerinden elde edilen veriler doğrultusunda Açımlayıcı Faktör Analizi sonucunda ortaya konan yapının, Doğrulayıcı Faktör Analizi sonucunda da doğrulandığı görülmüştür $(t>2.576$, $p<.01)$. Söz konusu değerlere ilişkin veriler Şekil 1'de sunulmuştur.

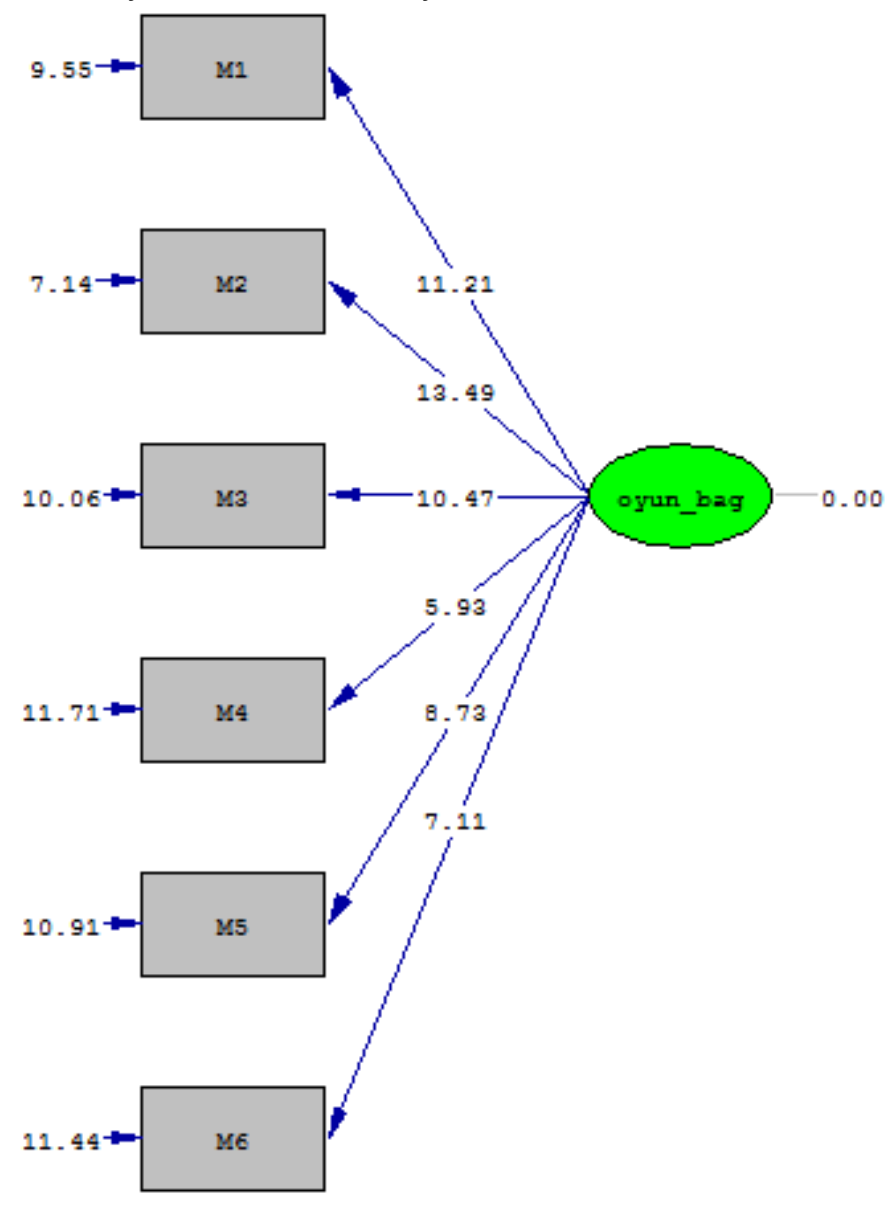

Chi-Square=19.46, df=9, P-value=0.02158, RMSEA=0.062

Şekil 1. Doğrulayıcı Faktör Analizi $t$ değerleri

\section{BULGULAR}

3.1. İlkokul 4. Sınıf öğrencilerinin bilgi ve iletişim teknolojileri kullanımı ile dijital oyun oynama alışkanlıklarının dağılımına yönelik bulgular

$\mathrm{Bu}$ bölümde araştırmanın örneklem grubunu oluşturan öğrencilere uygulanan Bilişim Teknolojileri Kullanımı anketinden elde edilen verilerin betimsel analizlerine yer verilmiştir.

Tablo 9. Sosyo-ekonomik düzey ve medya araçları sahipliği çapraz tablosu

\begin{tabular}{lccccccc}
\hline & & \multicolumn{6}{c}{ Sosyo-ekonomik düzey (medya sahipliği) } \\
\cline { 3 - 9 } & & \multicolumn{2}{c}{ Düşük } & \multicolumn{3}{c}{ Orta } & \multicolumn{2}{c}{ Yüksek } \\
\cline { 2 - 9 } & & $\mathbf{n}$ & $\mathbf{\%}$ & $\mathbf{n}$ & $\mathbf{\%}$ & $\mathbf{n}$ & \% \\
\hline \multirow{2}{*}{ Bilgisayar } & Var & 80 & 82,5 & 76 & 77,6 & 89 & 83,2 \\
& Yok & 17 & 17,5 & 22 & 22,4 & 18 & 16,8 \\
\hline \multirow{2}{*}{ Tablet Bilgisayar } & Var & 65 & 67,0 & 80 & 81,6 & 84 & 78,5 \\
& Yok & 32 & 33,0 & 18 & 18,4 & 23 & 21,5 \\
\hline
\end{tabular}

Tablo 9'da araştırmaya katılanların sosyo-ekonomik düzeylerine göre bilgisayara sahip olma durumları verilmiştir. Bilgisayara sahip olma durumu incelendiğinde düşük sosyo ekonomik düzeyden \%83 (97 ögrrenciden 80'i), orta sosyo ekonomik düzeyden \%78 (98 öğrenciden 76's1), yüksek sosyo ekonomik düzeyden \%83 (107 öğrenciden 89’u) bilgisayara sahip olduğu görülmektedir. Tablet 
bilgisayar için düşük sosyo ekonomik düzeyden \%67 (97 öğrenciden 65'i), orta sosyo ekonomik düzeyden \%82 (98 öğrenciden 80'i), yüksek sosyo ekonomik düzeyden \%79 (107 öğrenciden 84'ü) tablet bilgisayara sahiptir. Bilgisayara sahip olma durumlarında SED'e göre farklılıkların olmasının sebebi olarak, günümüzde medya araçlarına geniş bir fiyat aralığında ulaşılabilmesi ve bu araçların her kesim için ihtiyaç gibi görülmesi olarak yorumlanabilir. Araştırmaya katılan öğrencilerin akıllı telefona sahip olma durumlarına göre dağılımları Tablo 10'da verilmiştir.

Tablo 10. Öğrencilerin akıllı telefon ve SED çapraz tablosu

\begin{tabular}{lcc|cc}
\hline & \multicolumn{2}{c}{ Akıllı telefona sahip olma } & \multicolumn{2}{c}{ Aile bireylerinin akıllı telefonunu kullanma } \\
\cline { 2 - 5 } & Evet & Hayır & Evet & Hayır \\
nüşük & $26(\% 8,6)$ & $71(\% 23,5)$ & $55(\% 18,2)$ & $42(\% 13,9)$ \\
Orta & $29(\% 9,6)$ & $69(\% 22,8)$ & $60(\% 19,9)$ & $38(\% 12,6)$ \\
Yüksek & $48(\% 15,9)$ & $59(\% 19,5)$ & $61(\% 20,2)$ & $46(\% 15,2)$ \\
Toplam & $103(\% 34,1)$ & $199(\% 65,9)$ & $176(\% 58,3)$ & $126(\% 41,7)$ \\
\hline
\end{tabular}

Tablo 10'da öğrencilerin SED'e göre akıllı telefona sahip olma ve başkasının telefonunu kullanma durumlarına ilişkin veriler bulunmaktadır. Tabloya göre kendilerine ait akıllı telefonu bulunan öğrencilerin \%8,6'sı ( $\mathrm{f}=26)$ düşük SED'den, \%9,6'sı ( $\mathrm{f}=29)$ orta SED'den, \%15,9'u ( $\mathrm{f}=48)$ ise yüksek SED'den öğrencilerdir. Aile bireylerinin telefonlarını kullanma değişkenine bakıldığında ise öğrencilerin \%18,2'sinin ( $\mathrm{f}=55)$ düşük SED'den, 19,9'unun ( $\mathrm{f}=60)$ orta SED'den, \%20,2'sinin ise yüksek SED'den olduğu görülmüsşür. Çok büyük farklar olmamakla birlikte ak1llı telefona erişim durumu SED'e göre değişiklik göstermektedir. SED arttıkça telefona erişim oranları da artış göstermektedir. Araştırmaya katılan öğrencilerin internet kullanım durumlarına göre dağılımı Tablo 11'de verilmiştir.

Tablo 11. Sosyo-ekonomik düzey ve internet kullanımı çapraz tablosu

\begin{tabular}{lccccccc}
\hline & \multicolumn{6}{c}{ Sosyo-ekonomik düzey (internet kullanımı) } \\
\cline { 3 - 8 } & & \multicolumn{2}{c}{ Düşük } & $\mathbf{3}$ Orta & Yüksek \\
\cline { 2 - 8 } Evde & $\mathbf{N}$ & $\mathbf{\%}$ & $\mathbf{N}$ & $\mathbf{\%}$ & $\mathbf{N}$ & $\mathbf{\%}$ \\
\cline { 3 - 8 } & Var & 85 & 87,6 & 86 & 87,8 & 94 & 87,7 \\
& Yok & 12 & 12,4 & 12 & 12,2 & 13 & 12,3 \\
\hline Dişarda & Var & 46 & 47,7 & 49 & 50,0 & 52 & 48,6 \\
& Yok & 51 & 52,6 & 49 & 50,0 & 55 & 51,4 \\
\hline
\end{tabular}

Tablo 11'de araştırmaya katılan öğrencilerin sosyo ekonomik düzeylerine göre evlerinde internet bağlantısı olup olmadığına dair bulgular verilmiştir. Tabloya göre düşük sosyo ekonomik düzeyden seçilen okullardaki öğrencilerin evde internete erişim oranı 87,6 (97 öğrenciden 85'i), ev dışında internete erişim oranı ise 47,7 (97 öğrenciden 46's1)'dir. Orta sosyo ekonomik düzeyden seçilen okullardaki öğrencilerin evde internete erişim oranı 87,8 (98 öğrenciden 86 's1), ev dişında internete erişim oranı ise 50,0 (98 öğrenciden 49'u)'dir. Yüksek sosyo ekonomik düzeyden seçilen okullardaki öğrencilerin ise evde internete erişim oran 87,7 (107 öğrenciden 94'ü), ev dışında internete erişim oranı ise 48,6 (107 öğrenciden 52'si)'dır. Öğrencilerin sosyo ekonomik düzeye göre internete erişim oranlarının birbirine çok yakın olması günümüzde sosyo ekonomik düzeyin bu konuda belirleyici olmamasının göstergesi olarak yorumlanabilir. Toplumun her kesimi internete büyük oranda erişim sağlayabilmektedir. Araştırmaya katılan öğrencilerin internet kullanım amaçlarına göre dağılımları Tablo 12'de verilmiştir.

Tablo 12. Öğrencilerin internet kullanım amaçlarına göre dağılımları

\begin{tabular}{lcc}
\hline & \multicolumn{3}{c}{ Internet Kullanım Amacı } \\
\cline { 2 - 3 } Araştırma & $\mathbf{n}$ & $\mathbf{\%}$ \\
\cline { 2 - 4 } Oyun & 92 & 36,4 \\
Film İzleme & 34 & 30,5 \\
Müzik Dinleme & 32 & 11,3 \\
Sohbet & 26 & 10,6 \\
Kullanmiyor & 8 & 8,6 \\
\multicolumn{1}{c}{ Toplam } & 302 & 2,6 \\
\hline
\end{tabular}

Tablo 12'de öğrencilerin interneti kullanım amaçlarına ilişkin veriler bulunmaktadır. Buna göre öğrencilerin \%36,4'ü $(\mathrm{f}=110)$ interneti araştırma yapmak, \% 30,5'i (f=92) oyun oynamak, \%11,3'ü (f=34) film izlemek, \%10,6's1 (f=32) müzik dinlemek ve \%8,6's1 (f=26) sohbet etmek için kullanmaktadır. Öğrenciler interneti en çok araştırma yapmak ve oyun oynamak için kullandığı 
görülmektedir. İnternetin öğrenciler için çoğunlukla ödevlerine yardımcı ve eğlence aracı olarak görüldügü söylenebilir. Anket verilerine göre öğrencilerin 2,6 'sının $(\mathrm{f}=8)$ internet erişimi yoktur. Araştırmaya katılan öğrenci velilerinin bilgisayar, tablet ya da akıllı telefon kullanımına ilişkin koydukları kurallara göre dağılımları Tablo 13'de verilmiştir.

Tablo 13. Öğrenci velilerinin koydukları kurallara göre dağılımları

(1) Kural koymuyorlar

(2). "Ödevlerim bittikten sonra kullanmama izin veriyorlar."

\begin{tabular}{cc}
\multicolumn{2}{c}{ Aile Kuralları } \\
\hline $\mathbf{n}$ & $\mathbf{\%}$ \\
\hline 42 & 13,9 \\
73 & 24,2 \\
86 & 28,5 \\
20 & 6,6 \\
1 & 0,3
\end{tabular}

(3). "Süre sinırlaması koyuyorlar."

(4). "Sadece hafta sonu kullanmama izin veriyorlar."

(5). Diğer

Tablo 13'de araştırmaya katılan öğrencilerin ailelerinin medya araçlarının kullanımı için koydukları kurallara ilişkin veriler bulunmaktadır. En fazla iki adet seçeneğin işaretlenebildiği maddeye göre öğrencilerin \%13,9'una ( $\mathrm{f}=42)$ aileleri tarafından hiçbir kural koyulmamaktadır. Öğrencilerin $\% 86,1$ 'i ise medya araçlarını belli kurallar çerçevesinde kullanmaktadır. Anket verilerine göre öğrencilerin \%24,2'si ödevleri bittikten sonra, \%28,5'i süre sınırlamasıla, \%6,6's1 ise sadece hafta sonları medya araçlarını kullanmaktadır. Öğrencilerin \%0,3 medya araçlarını kullanma konusunda "diğer" maddesiyle farklı kurallar konulduğunu belirtmiştir. Öğrenciler "diğer" maddesi için "yemek yedikten sonra kullanmama izin veriyorlar.", "odamı topladıktan sonra kullanmama izin veriyorlar." gibi kurallar eklemişlerdir. Araştırmaya katılan öğrencilerin sosyo ekonomik düzey ve sosyal medya sahipliği çapraz tablosu Tablo 14'de verilmiştir.

Tablo 14. Sosyo ekonomik düzey ve sosyal medya sahipliği çapraz tablosu

\begin{tabular}{|c|c|c|c|c|c|c|c|c|}
\hline \multirow{6}{*}{ Facebook } & \multirow{4}{*}{ Kendisine ait } & \multirow{4}{*}{$\begin{array}{c}\text { Evet } \\
\text { Hayır }\end{array}$} & \multicolumn{2}{|c|}{ Düşük } & \multicolumn{2}{|c|}{ Orta } & \multicolumn{2}{|c|}{ Yüksek } \\
\hline & & & n & $\%$ & $\mathrm{n}$ & $\%$ & $\mathbf{n}$ & $\%$ \\
\hline & & & 45 & 14,9 & 56 & 18,5 & 59 & 19,5 \\
\hline & & & 52 & 17,2 & 42 & 13,9 & 48 & 15,9 \\
\hline & \multirow[t]{2}{*}{ Başkasına ait } & Evet & 33 & 10,9 & 29 & 9,6 & 34 & 11,3 \\
\hline & & Hayır & 64 & 21,2 & 69 & 22,8 & 73 & 24,2 \\
\hline \multirow{4}{*}{ Instagram } & \multirow[t]{2}{*}{ Kendisine ait } & Evet & 16 & 5,3 & 25 & 22,8 & 25 & 8,3 \\
\hline & & Hayır & 81 & 26,8 & 73 & 24,2 & 82 & 27,2 \\
\hline & \multirow[t]{2}{*}{ Başkasına ait } & Evet & 18 & 6,0 & 12 & 4,0 & 20 & 6,6 \\
\hline & & Hayır & 79 & 26,2 & 86 & 28,5 & 87 & 28,8 \\
\hline \multirow{4}{*}{ Snapchat } & \multirow[t]{2}{*}{ Kendisine ait } & Evet & 16 & 5,3 & 20 & 6,6 & 21 & 7,0 \\
\hline & & Hayır & 81 & 26,8 & 78 & 25,8 & 86 & 28,5 \\
\hline & \multirow[t]{2}{*}{ Başkasına ait } & Evet & 13 & 4,3 & 14 & 4,6 & 24 & 7,9 \\
\hline & & Hayır & 84 & 27,8 & 84 & 27,8 & 83 & 27,5 \\
\hline \multirow{4}{*}{ Twitter } & \multirow[t]{2}{*}{ Kendisine ait } & Evet & 12 & 4,0 & 10 & 3,3 & 12 & 4,0 \\
\hline & & Hayır & 85 & 28,1 & 88 & 29,1 & 95 & 31,5 \\
\hline & \multirow[t]{2}{*}{ Başkasına ait } & Evet & 8 & 2,6 & 9 & 3,0 & 10 & 3,3 \\
\hline & & Hayır & 89 & 29,5 & 89 & 29,5 & 97 & 32,1 \\
\hline
\end{tabular}

Tablo 14'e göre öğrencilerin \%13,6'sının ( $\mathrm{f}=41$ ) hem kendisine ait hem de başkalarına ait hesaplardan, \%39,4'ünün ( $\mathrm{f}=119$ ) sadece kendine ait hesaptan, \%18,2'sinin ( $\mathrm{f}=55)$ ise sadece başkalarına ait hesaplardan Facebook'a erişim sağladığ görülmüştür. Öğrencilerin \%5,6'sının (f=17) hem kendisine ait hem de başkalarına ait hesaplardan, \%16,2'sinin (f=49) sadece kendine ait hesaptan, $\% 10,9$ 'unun $(\mathrm{f}=33)$ ise sadece başkalarına ait hesaplardan Instagram'a erişim sağladığ görülmüştür. Öğrencilerin \%7,3'ü ( $\mathrm{f}=22)$ hem kendisine ait hem de başkalarına ait hesaplardan, \%1 1,3'ünün ( $\mathrm{f}=34)$ sadece kendine ait hesaptan, \%9,6'sının ( $\mathrm{f}=29)$ ise sadece başkalarına ait hesaplardan Snapchat'e erişim sağladığ1 görülmüştür. Öğrencilerin \%3'ünün $(\mathrm{f}=9)$ hem kendisine ait hem de başkalarına ait hesaplardan, \%8, 3'ünün ( $\mathrm{f}=25)$ sadece kendine ait hesaptan, \%6'sının ( $\mathrm{f}=18)$ ise sadece başkalarına ait hesaplardan Twitter'a erişim sağladığı görülmüştür. Facebook \%55'lik (f=167) oran ile ilkokul 4. Sinıf öğrecilerinin en çok tercih ettği sosyal ağ olarak karşımıza çıkmaktadır. Henüz on yaşında olan kullanıcıların sosyal medya tercihleri dikkat çekici sonuç olarak ifade edilebilir.

Öğrencilerin oyun oynama sıklığına göre dağılımları Tablo 15 'de verilmiştir. Tabloya göre öğrencilerin \%34,4'ü (f=104) her gün, \%13,6's1 ( $\mathrm{f}=41$ ) haftada 3-4 gün, 43,3’ü ( $\mathrm{f}=131)$ sadece hafta sonu oyun oynarken araştırmaya katılan öğrencilerin \% $\%, 6$ 's1 $(\mathrm{f}=26)$ hiç oyun oynamadığını belirtmiştir. 
Tablo 15. Öğrencilerin oyun oynama sıklığına göre dağılımları

\section{Oyun Oynama Sıklığı}

Hiç oynamam

Sadece hafta sonu oynarım

Haftada 3-4 gün oynarım

Her gün oynarım

Toplam

\begin{tabular}{cccc}
\hline Hiç oynamam & 2 saatten az & 2-4 saat arası & 4 saatten fazla \\
\hline 26 & 0 & 0 & 0 \\
0 & $96(\% 73,3)$ & $31(\% 23,7)$ & $4(\% 3,1)$ \\
0 & $25(\% 73,3)$ & $16(\% 39,0)$ & 0 \\
0 & $60(\% 57,7)$ & $39(\% 37,5)$ & $5(\% 4,8)$ \\
$26(\% 8,6)$ & $181(\% 59,9)$ & $86(\% 28,5)$ & $9(\% 3)$ \\
\hline
\end{tabular}

Araștırma örneklemini oluşturan ilkokul 4. Sınıf öğrencilerinin \%91'nin ( $f=276)$ dijital oyun oynadığını belirtmesi diğer önemli bir bulgudur. Oyun oynama sıklığında ise, sadece hafta sonu oynadığını belirten \%47 (f=131) ve her gün oynadığını belirten \%38 (f=104) çoğunluğu oluşturmaktadır. Hafta sonu oyun oynayan öğrencilerin \%73,3’ü (f=96) günlük 2 saatten az, \%23,3’ü $(\mathrm{f}=31)$ 2-4 saat aras1, \%3,1i ( $\mathrm{f}=4)$ ise 4 saatten fazla; haftada 3-4 gün oyun oynayan öğrencilerin $\% 73,3$ 'ü $(\mathrm{f}=25) 2$ saatten az, \%39'u ( $\mathrm{f}=16)$ 2-4 saat aras1 oyun oynamaktadır. Her gün oyun oynayan öğrencilerin \%57,7'si (f=60) 2 saatten az, \%37,5'i (f=39) 2-4 saat arası, \%4,8'i (f=5) ise 4 saatten fazla oyun oynamaktadır.

\subsection{Demografik değişkenlerine bağlamında ilkokul 4. Sınıf öğrencilerinin dijital oyun bağımlılığına ilişkin bulgular}

$\mathrm{Bu}$ bölümde "Cinsiyet, akıllı telefona sahip olma, akıllı telefon kullanım sıklığı, dijital oyun oynama sıklığı, başkasının Facebook hesabına giriş yapma ve sosyo-ekonomik düzey değişkenleri, ilkokul 4. Sınıf öğrencilerini dijital oyun bağımlılı̆̆ bakımından manidar bir şekilde ayırabilmekte midir?" sorusuna ait bulgulara yer verilmiştir. Araştırma alt amacı doğrultusunda öncelikle dijital oyun bağımlısı olarak tanımlanacak öğrenciler Lemmens, Valkenburg ve Peter'ın (2009) belirttiği gibi toplam madde sayısının en az yarısına 3 ve üzeri işaretleyen öğrenciler dijital oyun bağımlısı olarak belirlenmiştir. Ardından, dijital oyun bağımlılığını manidar bir şekilde ayıran değişkenlerin belirlenmesi Chaid analizi yapılmıştır.

Chaid analizinde ilk olarak modele ilişkin özet bilgilerin yer aldığı tablo verilmektedir. Buna göre modelde bağımlı değişken dijital oyun bağımlılı̆̆ı, bağımsız değişkenler ise cinsiyet, kendisine ait telefonu olması, dijital oyun oynama sıklı̆̆ı, sosyo-ekonomik düzey, kendisine ait Facebook hesabının olması ile başkasına ait Facebook hesabını kullanma durumlarıdır. Ancak bağımsız değişkenlerden sadece cinsiyet, dijital oyun oynama sıklığı ve başkasının facebook hesabını kullanma başarıyı anlamlı bir şekilde yordadığı görülmüştür. Çalışmada sonrasında Chaid analizi ile beklenen ve gözlenen değerlere ilişkin sınıflandırma tablosu Tablo 16'da verilmiştir.

Tablo 16. Bağımlılık Durumuna İlişkin Sınıflama Tablosu

\begin{tabular}{lccc}
\hline & Bağımlı değil & Bağımlı & Bağımlılık Yüzdesi \\
\hline Bağımlı değil & 260 & - & $100,0 \%$ \\
Bağımlı & 42 & 0 & - \\
Toplam & $100,0 \%$ & $0,0 \%$ & $86,1 \%$ \\
\hline
\end{tabular}

Tablo 16 incelendiğinde kurulan modele göre bağımlı değişkenin ne kadarının doğru olarak sinıflandığı gösterilmektedir. Bu bağlamda araştırma örnekleminden 42 öğrenci (\%14) dijital oyun bağımlısı olarak belirlenmiş ve yanlış bir sınıflandırmanın olmadığı görülmektedir. Programın sınıflama tablosuna ek olarak verdiği risk değerinde sistemin yanılma payı verilmektedir. Buna göre kurulan ağaç grafiği modelinin hesaplanan risk değeri ,139 olarak belirlenmiştir. Bu sonuca göre model tarafından yapılan sınıflamanın yanlış sınıflandırma riski yaklaşık \% 14'dür. Dijital oyun bağımlıı̆ı̆ına göre bağımlı ya da bağımlı olmayan öğrencileri sınıflandırmak için hangi değişkenlerin belirleyici olduğu ve bunların önem sıralarına ilişkin analiz sonuçları Şekil 2'de gösterilmiştir. 


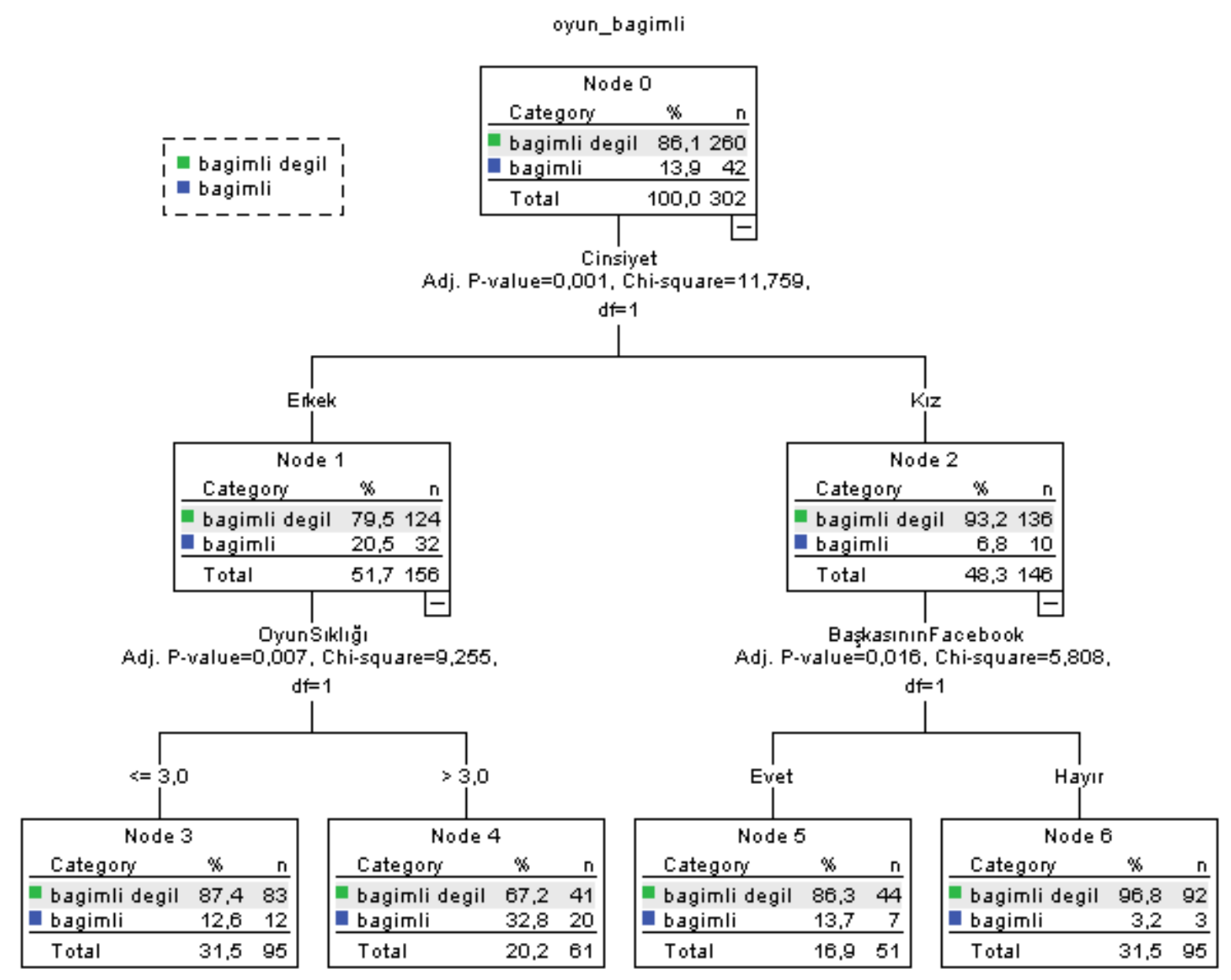

Şekil 2. Dijital Oyun Bağımlılı̆̆ Durumuna İlişkin Karar Ağacı Modeli

Şekil 2 incelendiğinde öğrencilerin \%86,1'sinin bağımlı değil, \%13,9'nun ise bağımlı olarak sınıflandırıldığı görülmektedir. Dijital oyun bağımlılığını tek yordayıcı bağımsız değişkenin cinsiyet olduğu görülmektedir. Erkek öğrencilerin oluşturduğu ve dijital oyun bağımlılığını en iyi açıklayan 1. Düğüme (Node 1) bakıldığında 124 erkek öğrencinin (\% 79,5) bağımlı değil, 32 erkek öğrencinin $(\% 20,5)$ bağımlı olduğu görülmektedir. Ki-kare değerine bakıldığında $\left(\chi^{2}=9.255, p=.007\right)$ bağımlı değişken ile istatistiksel olarak anlamlı ve tek ilişkili olan bağımsız değişken olan cinsiyetin, erkek öğrenciler olan kümesini açıklayan bağımsız değişkenin de oyun oynama sıklığı olduğu görülmektedir. Karar ağacı yapısının 0, 3 ve 4. Düğümleri incelendiğinde dijital oyun oynama sıklığı için 3 değerinin kesme noktası olarak belirlendiği görülmektedir. Diğer bir deyişle toplam örneklem sayısının \%31.5'i bu yol izlenerek dijital oyun bağımlılığı hakkında bir sonuca ulaşılabilir. Üç gün ve altında dijital oyun oynayan 83 erkek öğrencinin bağımlı olmadığı, 12 öğrencinin ise bağımlı olduğu söylenebilir. Söz konusu 12 erkek öğrenci (\%12.6), düğüm 0,1 ve düğüm 3 ağaç yapısının izlenmesi sonucu ortaya çıkan, erkek ve 3 gün ya da daha az sayıda oyun sıklığı gösteren öğrencileri oluşturmaktadır. Söz konusu yol izlendiğinde 83 erkek öğrencinin (\% 87.4) bağımlı olmadığı söylenebilir.

Kız öğrencilerin oluşturduğu ve dijital oyun bağımlılığını açılayan 2. Dügüme (Node 2) bakıldığında $136 \mathrm{kız}$ öğrencinin $(\% 93.2,5)$ bağımlı değil, $10 \mathrm{kız} \mathrm{öğrencinin}(\% 6,8)$ bağımlı olduğu görülmektedir. Ki-kare değerine bakıldığında $\left(\chi^{2}=5.808, \mathrm{p}=.016\right)$ bağımlı değișken ile istatistiksel olarak anlamlı ve tek ilişkili olan bağımsız değişken olan cinsiyetin, kız öğrenciler olan kümesini açıklayan bağımsız değişkenin de başkasının facebook hesabını kullanma olduğu görülmektedir. Dügü̈m 0,2 ve 5 yolu izlendiğinde başkasının facebook hesabını kullanan kız öğrencilerin 7'sinin (\%13.7) bağımlı olduğu, 44'nün (\%86.3) bağımlı olmadığı sonucuna ulaşılmaktadır. Ayrıca bağımlı dijital oyun bağımlısı öğrencileri sınıflandırmada hangi dügümlerin daha fazla bilgi verdiğini belirlemek amacıyla düğümlere ilişkin kazanç değerleri Tablo 17'de verilmiştir. 
Tablo 17. Dijital Oyun Bağımlılığı Durumuna İlişkin Kazanç Değerleri

\begin{tabular}{lcccccc}
\hline Düğ̈̈̈m & \multicolumn{2}{c}{ Düğ̈̈̈m } & \multicolumn{2}{c}{ Kazanç } & Cevap Oranı & İndeks \\
\cline { 2 - 5 } & $\mathrm{n}$ & $\%$ & $\%$ & $\%$ & & \\
\hline 4 & 61 & $20,2 \%$ & 20 & $47,6 \%$ & $32,8 \%$ & $235,8 \%$ \\
3 & 95 & $31,5 \%$ & 12 & $28,6 \%$ & $12,6 \%$ & $90,8 \%$ \\
5 & 51 & $16,9 \%$ & 7 & $16,7 \%$ & $13,7 \%$ & $98,7 \%$ \\
6 & 95 & $31,5 \%$ & 3 & $7,1 \%$ & $3,2 \%$ & $22,7 \%$ \\
\hline
\end{tabular}

Tablo 17. incelendiğinde dijital oyun bağımlılığını açıklamada en başarılı düğümün haftada 3 günden fazla oyun oynayan erkek öğrenciler olduğu görülmektedir. Bu özellikteki öğrencilerin tüm model için başarı oranı yaklaşı \% 48 olarak belirlenmiştir. Bu oran haftada 3 gün ya da daha az dijital oyun oynayan erkek öğrenciler için yaklaşık \%29 olarak ortaya konmaktadır. Başkasının Facebook hesabını kullanan kız öğrenciler için başarı oranı yaklaşık \%18 olarak görülürken, başkasının Facebook hesabını kullanmayan kız öğrenciler için ise $\% 7$ olduğu söylenebilir. Modelin bir bütün olarak başarısını değerlendirmede kullanılabilecek grafikler ise hedef kategoriye ilişkin başarı eğrisi ve kümülatif dizin grafiğidir. Hedef kategoriye ilişkin başarı eğrisi Şekil 3' de verilmiştir.



Şekil 3. Hedef kategoriye ilişkin başarı eğrisi

Hedef kategoriye ilişkin başarı eğrisini yorumlamada söz konusu eğrinin \%100'e kadar yükselip orada kesilmesi önem göstermektedir (Aksu \& Karaman, 2016). Şekil 3'deki eğri \%50 civarında kesilmesi modelin başarısını açıklamada soru işareti oluşturmaktadır. Bu noktada kümülatif dizin grafiği de mevcut durumu yorumlamada kullanılmalıdır. Söz konusu grafik Şekil 4'de verilmiştir. 




Şekil 4. Kümülatif dizin grafiği

Şekil 4'de verilen kümülatif dizin grafiği incelendiğinde \%100'ün üzerinde başlayarak \%100' e kadar kademeli olarak azalması nedeniyle belirtilen ölçütleri sağladığı söylenebilir (Aksu \& Karaman, 2016). Bu bağlamda modelin başarısı için Hedef kategoriye ilişkin başarı eğrisi ve kümülatif dizin grafiği birlikte değerlendirildiğinde modelin kabul edilebilir başarı gösterdiği söylenebilir.

\section{TARTIŞMA VE SONUÇ}

$\mathrm{Bu}$ çalışmada İlkokul 4. Sınıf öğrencilerinin bilgi dijiteknolojileri kullanımı ile dijital oyun oynama alışkanlıklarının dağılımı ve dijital oyun bağımlılığı bakımından manidar bir şekilde ayıran değişkenler araştırılmıştır.

Araştırma sonuçlarına göre katılımcıların \%81,1'inin ( $\mathrm{f}=245)$ bilgisayara, \%75,8'inin $(\mathrm{f}=229)$ tablet bilgisayara, \%34,1'inin ak1llı telefona (kendine ait) sahip olduğu görülmüştür, \%58,3'ünün ( $\mathrm{f}=176)$ aile bireylerinin telefonlarını kullandığını belirtmiştir. Örneklem grubunun \% 87,7'sinin ( $\mathrm{f}=265$ ) evinde internet bağlantısı bulunurken, \%48,7'si ev dışında internete bağlanabilmektedir. Taylan, Kara ve Durğun'a (2017) göre öğrencilerin \%71'lik kesimi "Evinizde internet bağlantıs1 bulunuyor mu?" sorusuna evet cevabını vermiştir. Sonuçlar çoğu evde internet bağlantısı olduğunu göstermektedir. İnternete artık günümüzde her kesim rahat rahat ulaşabilmektedir. İnternet kullanımı dağılımlarına göre öğrencilerin \% 31,8'i (f=96) interneti oyun oynamak için, \%8,6's1 (f=26) sohbet, $\% 10,9$ 'u (f=33) müzik dinlemek, \%11,3’ü ( $\mathrm{f}=34)$ film izlemek ve \%37,4'ü (f=113) araştırma yapmak için kullanmaktadır. Öğrenciler interneti en çok araştırma yapmak ve internet üzerinden oynadıkları oyunlar için kullanmayı tercih etmektedir.

Örneklem grubundaki öğrencilerin medya araçlarını kullanımları noktasında ebeveynleri tarafından getirilen sınırlamalar incelendiğinde öğrencilerin \%13,9'una $(\mathrm{f}=42)$ aileleri tarafından hiçbir kural koyulmazken, \%86,1'i ( $\mathrm{f}=260)$ ise medya araçlarını belli kurallar çerçevesinde kullandığ görülmüştür. Elde edilen bulgulara göre öğrencilerin \%24,2'si ( $\mathrm{f}=73$ ) ödevleri bittikten sonra, $\% 28,5$ ' $\mathrm{i}$ ( $\mathrm{f}=86)$ süre sınırlamasıyla, $\% 6,6$ 'sı $(\mathrm{f}=20)$ ise sadece hafta sonları medya araçlarını kullanmaktadır. Öğrencilerin $0,3^{\prime} \ddot{\mathrm{u}}(\mathrm{f}=1)$ medya araçlarını kullanma konusunda farklı kurallar konulduğunu belirtirken 17,5 'i (f=53) ödevleri bittikten sonra ve süre sinırlaması kurallarıyla, $\% 2$ 'si ( $\mathrm{f}=6$ ) sadece hafta sonu ve ödevleri bittikten sonra, $\% 5^{\prime} \mathrm{i}(\mathrm{f}=15)$ sadece hafta sonları süre sınırlamasıyla medya araçlarına ulaşabilmektedir. Burak (2013) tarafindan yapılan araştırmaya göre öğrencilerin \%90’1 ebeveynlerinin bilgisayar oyunu oynama konusunda kural koyduklarını, \%10'nun da ebeveynlerinin bilgisayar oyunu oynama konusunda kural koymadıkları belirlenmiştir. Bu sonuç araştırma bulguları ile yaklaşık olarak benzer sonuçları işaret etmektedir.

Katılımcıların en çok kullandıkları sosyal medya, Facebook'tur. Öğrencilerin yarısından çoğu (\%53) kendilerine ait Facebook hesabına sahip olduklarını belirtmişlerdir. Seferoğlu ve Yıldız'ın (2014) ortaokul 5 ve 6 . Sınıf öğrencilerinde \%74 oranında Facebook kullanım oranı göz önüne alındığında sosyal medya kullanımının oldukça küçük yaşlardan itibaren başladığı söylenebilir. İlkokul 4. Sınıf öğrencilerinin öğrencilerin dijital oyun oynama alışkanlıklarının dağılımları incelendiğinde \%92,1'inin ( $\mathrm{f}=278$ ) medya araçlarını oyun oynamak için kullandığı görülmüştür. Öğrencilerin \%34,4’ü (f=104) her 
gün, \%13,6's1 ( $\mathrm{f}=41$ ) haftada 3-4 gün, 43,3'ü ( $\mathrm{f}=131$ ) sadece hafta sonu oyun oynarken araştırmaya katılan öğrencilerin \%8,6'sı $(\mathrm{f}=26)$ hiç oyun oynamadığını belirtmiştir. Öğrencilerin büyük çoğunluğunun bilgisayar, tablet ya da akıllı telefonu oyun aracı olarak gördükleri söylenebilir.

İkinci alt amaca ait bulgulara bakıldığında öğrencilerin çoğunun $(\% 86,1 / \mathrm{f}=260)$ bağımlı olmadığı, \%13,9'unun (f=42) ise dijital oyun bağımlısı olduğu belirlenmiştir. Bu durumda bağımlılı̆̆ın ilkokul 4. sınıf öğrencilerinde çok yaygın olmadığı ancak dikkat edilmesi gereken noktada olduğu söylenebilir. Bağımlığı etkileyen değişkenlere bakıldığında öğrencilerin dijital oyun bağımlılı̆̆ını etkileyen en önemli yordayıcı değişkenin cinsiyet olduğu görülmüştür. Sonuçlara göre erkek öğrenciler kız öğrencilere göre daha fazla bağımlılık göstermektedir. Erkek öğrencilerin \%20'si (f=32) dijital oyunlara bağımlıyken, kız öğrencilerde bu oran \%6,8 ( $\mathrm{f}=10)$ olarak bulunmuştur. Griffiths ve Hunt (1995), Griffiths ve Davies (2005), Erboy (2010), Horzum (2011), Şahin ve Tuğrul (2012), Vollmer, Randler, Horzum ve Ayas (2014), Bilgin (2015) araştırmalarında benzer sonuçlara ulaşmışlardır. Erkek öğrencilerde bağımlılığ yordayan ikincil değişken ise oyun oynama sıklığı olarak bulunmuştur. Haftada üç günden daha fazla oyun oynanması durumunda dijital oyun bağımlılığını olumsuz olarak etkilemektedir. Bu sonuç Güllü, Arslan, Dündar ve Murathan (2012) tarafından yapılan araştırmada cinsiyet ve günlük bilgisayar kullanım süresi olarak yer almıştır.

Cinsiyet değişkeninde kız öğrencilerin dijital oyun bağımlılıklarını en iyi açıklayan bağımsız değişken, başkasının Facebook hesabını kullanmadır. Başkasının Facebook hesabını kullanan kız öğrenciler, başkasının Facebook hesabını kullanmayanlara göre daha fazla bağımlılık göstermektedir. Bu durumun sebebi olarak ilkokul öğrencilerinin yaş sınırının yanında kız öğrencilere kültürel açıdan sosyal medya kullanımında kısıtlamalar getirilmesini düşündürmektedir. Bunun yanında başkalarının Facebook hesabıyla erişmesi ve Facebook'u daha çok oyun oynamak için kullanması gösterilebilir.

Araştırma sonuçlarına göre ailelerin ve çocukların medya kullanımı konusunda bilinçlendirilmesi önemli olarak değerlendirilmektedir. Ayrıca Steinberg'in (2011) de belirttiği gibi sağlıklı oyun alışkanlıklarının geliştirilmesinde zaman sınırlamalarının ayarlaması, ücretsiz ebeveyn hesaplarını kullanmas1, fiziksel aktiviteyle oyun dengesinin kurulmas1, ailecek aktif olunabilecek dijital oyunların oynanması, çocukların oyun bağımlılı̆̆ ve oyunların zararlı etkilerinden korunması açısından önemli olduğu düşünülmektedir. Çalışma Denizli ilinde sosyo-ekonomik düzeye göre belirlenen altı okuldaki 4. sınıf öğrencileriyle yürütülmüştür. Farklı bölge ve illerde, farklı yaş gruplarında benzer çalışmalar yapılabilir, bilgisayar oyun bağımlılığı üzerinde etkisi incelenmeyen farklı değişkenler araştırılabilir. Bunun yanında aile ve öğretmenlerin de dahil edildiği daha kapsamlı çalışmaların yapılması önerilir. 


\section{KAYNAKLAR}

Aksu, G., \& Karaman, H. (2016). Herkes için çok değişkenli istatistik, Cem Oktay Güzeller (Ed.), Chaid Analizi (pp.251-272). Ankara: Maya Akademi.

Altıntuğ, N. (2012). Kuşaktan kuşağa tüketim olgusu ve geleceğin tüketici profili. Organizasyon ve Yönetim Bilimleri Dergisi, 4(1), 203-212.

Alwin, D. F. (2002). Generations X, Y And Z: Are They Changing America. American Sociological Association, Contexts, 42(1), 42- 51.

Arıcak, O, T., Dinç, M., Yay, M., \& Griffiths, M. D. (2019). İnternet oyun oynama bozukluğu ölçeği kısa formunun (İOOBÖ9-KF) Türkçe'ye uyarlanması: Geçerlik ve güvenirlik çalışması. Addicta:The Turkish Online Journal on Addictions, 6(1), 1-22, doi:10.15805/addicta.2019.6.1.0027.

Atal, D., \& Usluel, Y. K. (2011). İlköğretim öğrencilerinin okul içinde ve dışında teknoloji kullanımları. Hacettepe Üniversitesi Ë̆itim Fakültesi Dergisi, 41(41), 24-35.

Aydoğdu Karaaslan, İ. (2015). Dijital oyunlar ve dijital şiddet farkındalığı: Ebeveyn ve çocuklar üzerine yapılan karşılaştırmalı bir analiz. Uluslararası Sosyal Araştırmalar Dergisi, 8(36), 806-818.

Bilgin, H. C. (2015). Ortaokul öğrencilerinin bilgisayar oyun bağımlıllk düzeyleri ile iletişim becerileri arasindaki iliş̧ki. Yayımlanmamış Yüksek Lisans Tezi, Pamukkale Üniversitesi Eğitim Bilimleri Enstitüsü, Denizli.

Bostan, B., \& Tingöy, Ö. (2015). Dijital oyunlar: Tasarım gereksinimeri ve oyuncu psikolojisi. Online Academic Journal of Information Technology, 6(19), 7-22, doi: 10.5824/1309---1581.2015.2.001.x.

Burak, Y. (2013). Bilgisayar oyunlarının ilköğretim birinci kademe ögrrencilerinin saldırganlık düzeylerine etkisinin incelenmesi. Yayımlanmamış Yüksek Lisans Tezi, Trakya Üniversitesi Sosyal Bilimler Enstitüsü, Edirne.

Büyüköztürk, Ş. (2002). Faktör analizi: Temel kavramlar ve ölçek geliştirmede kullanımı. Kuram ve uygulamada eğitim yönetimi, 32(32), 470-483.

Curtis, D., D., \& Lawson, M., J. (2002). Computer advanture games as problem-solving environments. International Education Journal, 3(4), 43-56.

Çukurbaşı, B., \& İşman A. (2014). Öğretmen adaylarının dijital yerli özelliklerinin incelenmesi (Bartın Üniversitesi örneği). Bartın Üniversitesi Eğitim Fakültesi Dergisi, 3(1), 28-54.

Deveci, S. E., Açık Y., Gülbayrak C., Demir A. F., Karadağ M. \& Koçdemir E. (2007). İlköğretim öğrencilerinin cep telefonu, bilgisayar, televizyon gibi elektromanyetik alan oluşturan cihazları kullanım sıklı̆ı. Fırat Tip Dergisi, 12(4), 279-289.

Eichenbaum A., Bavelier, D., \& Green, C., S. (2014). Video games: Play that can do serious good. American Journal of Play, 7(1), 50-72.

Erboy, E. (2010). İlköğretim 4. ve 5. Sinıf öğrencilerinin bilgisayar oyun bağımlılı̆̆ına etki eden faktörler. Yayımlanmamış Yüksek Lisans Tezi, Adnan Menderes Üniversitesi Sosyal Bilimler Enstitüsü, Aydın.

Erkuş, A. (2017). Davranı̧̧ bilimleri için bilimsel araştırma süreci. Ankara: Seçkin Yayıncılık.

Fraenkel, J. R., \& Wallen, N. E. (2009). The nature of qualitative research. How to design and evaluate research in education, Seventh edition. Boston: McGraw-Hill, 420.

Granic, I., Lobel, A., \& Engels, R. (2014). The benefits of playing video games. American Psychologist, 69(1), 66-78, doi: $10.1037 / \mathrm{a} 0034857$.

Griffiths, M.D. \& Davies, M.N.O. (2005). Videogame addiction: Does it exist? In J. Goldstein \& J. Raessens (Hrsg.), Handbook of Computer game studies. s. 359-368. Boston: MIT Press.

Griffiths, M. D., \& Hunt, N. (1995). Computer game playing in adolescence: Prevalence and demographic indicators. Journal of Community \& Applied Social Psychology, 5(3), 189-193.

Gökçearslan, Ş., \& Durakoğlu, A. (2014). Ortaokul öğrencilerinin bilgisayar oyunu bağımlılık düzeylerinin çeşitli değişkenlere göre incelenmesi. Dicle Üniversitesi Ziya Gökalp Eğitim Fakültesi Dergisi, 23, 419-435.

Güllü, M., Arslan, C., Dündar A., \& Murathan F. (2012). İlköğretim öğrencilerinin bilgisayar oyun bağımlılıklarının incelenmesi. Adlyaman Üniversitesi Sosyal Bilimler Enstitüsü Dergisi, 5(9), 89-100.

Hamlen, K. R. (2018). General problem-solving styles and problem-solving approaches in video games. Journal of Educational Computing, 56(4), 467-484, doi: 10.1177/0735633117729221.

Hazar, Z., \& Hazar, M. (2017). Çocuklar için dijital oyun bağımlılığı ölçeği. Journal od Human Sciences, 14(1), 203-216.

Horzum, M. B. (2011). İlköğretim öğrencilerinin bilgisayar oyunu bağımlılık düzeylerinin çeşitli değişkenlere göre incelenmesi. Eğitim ve Bilim, 36(159), 56-68.

Lemmens, J. S., Valkenburg, P. M., \& Peter, J. (2009). Development and validation of a game addiction scale for adolescents. Media Psychology, 12, 77-95.

O'Hagan, M. (2018), Game localization:A critical overview and implications for audiovisual translation. The Routledge Handbook of Audiovisual Translation:Routledge, doi:10.4324/9781315717166-10.

Pallant, J. (2015). Spss kullanma kılavuzu: Spss ile adım adım veri analizi. (S, Balcı \& B, Ahi, Çev), Ankara: Anı Yayıncilik.

RTÜK (2013). Türkiye'de Çocukların Medya Kullanma Alışkanlıkları. İstanbul: Bizim Matbaa. 
Sakarya S., Tercan İ., \& Çoklar A. N.(2011). İlköğretim öğrencilerinin interneti ve arama motorlarını kullanım durumları. Education Science, 7(1), 348-354.

Seferoğlu, S. S., \& Yıldız, H. (2013). Dijital çağın çocukları: İlköğretim öğrencilerinin facebook kullanımları ve internet bağımlılıkları üzerine bir araştırma. Iletişim ve Diplomasi, 2, 31-48.

Steinberg, S. (2011). The modern parent's guide to kids and video games. Lilburn:Power Play Publishing.

Sprenger, M. (2010). Brain-Based teaching in the digital age. ASCD. 1703 North Beauregard Street, Alexandria, VA 22311-1714.

Şahin, C., \& Tuğrul, V. M. (2012). İlköğretim öğrencilerinin bilgisayar oyunu bağımlılık düzeylerinin incelenmesi. Zeitschrift für die Welt der Türken/Journal of World of Turks, 4(3), 115-130.

Şimşek, Ö. F. (2007). Yapısal Eşitlik Modellemesine Giriş Temel İlkeler ve LISREL Uygulamaları. Ankara: Ekinoks Yayınları.

Taylan, H. H., Kara, H. Z., \& Durğun, A. (2017). Ortaokul ve lise öğrencilerinin bilgisayar oyunu oynama alışkanlıkları ve oyun tercihleri üzerine bir araştırma. PESA Uluslararası Sosyal Araştırmalar Dergisi, 3(1), 78-87.

Toran, M., Ulusoy, Z., Aydın, B., Deveci, T., \& Akbulut, A. (2016). Çocukların dijital oyun kullanımına ilişkin annelerin görüşlerinin değerlendirilmesi. Kastamonu Ĕ̆itim Dergisi, 24(5), 2263-2278.

TÜİK (2017, Ağustos). Hanehalkı Bilişim Teknolojileri Kullanım Araştırması. 12.12.2017, http://www.tuik.gov.tr/PreHaberBultenleri.do?id=24862

Ulusoy, A., \& Bostanc1, M. (2014). Çocuklarda sosyal medya kullanımı ve ebeveyn rolü. International Journal of Social Science, 28, 559-572.

Vollmer, C., Randler, C., Horzum, M. B., \& Ayas, T. (2014). Computer game addiction in adolescents and its relationship to chronotype and personality. Sage Open, 4(1), 1-9. doi:10.1177/2158244013518054.

Yalçın Irmak, A., \& Erdoğan, S. (2015). Dijital oyun bağımlılığı ölçeği Türkçe formunun geçerliliği ve güvenirliliği. Anatolian Journal of Psychiatry, 16(1), 10-18.

Yalçın Irmak, A., \& Erdoğan, S. (2016). Ergen ve genç yetişkinlerde dijital oyun bağımlılığı: Güncel bir bakış. Türk Psikiyatri Dergisi, 27(2), 128-137.

Yüksekbilgili, Z. (2015). Türkiye'de y kuşağının yaş aralığı. Elektronik Sosyal Bilimler Dergisi, 14(53), 259267. 